\title{
TILLER SIZE/POPULATION DENSITY COMPENSATION IN GRAZED COASTCROSS BERMUDAGRASS SWARDS
} \author{
Guilherme Silveira Pedreira ${ }^{2}$ \\ ${ }^{1}$ Graduate Student in Animal Science and Pastures - USP/ESALQ. \\ ${ }^{2}$ Depto. de Produção Animal - USP/ESALQ, C.P. 9 - CEP: 13418-900 - Piracicaba, SP. \\ ${ }^{3}$ FAPESP Fellow. \\ CAPES Fellow. \\ *Corresponding author <scdsilva@carpa.ciagri.usp.br>
}

André Fischer Sbrissiaa, Roberta Aparecida Carnevallii,4; Luiz Felipe de Moura Pinto ${ }^{1,4}$; Jaílson Lara Fagundes ${ }^{1,4}$; Carlos

\begin{abstract}
Several compensatory mechanisms in pastures do not allow optimisation of responses from the processes of herbage production and utilisation. Compensation due to tiller size/density relationships is one of these mechanisms. This experiment evaluated this process for Coastcross bermudagrass and compared the responses to those reported for temperate forages. Treatments were "steady state" sward surface heights of 5, 10, 15, and $20 \mathrm{~cm}$ that were maintained from August, 1998, through July, 1999 by sheep grazing. The experimental design was a randomised complete block, replicated four times. Pasture responses were evaluated on four separate dates (15/12/1998, 25/01/1999, 07/04/1999 and 04/07/1999) with respect to: tiller population density, tiller weight, leaf mass and leaf area per tiller and herbage mass (biomass). Tiller volume, leaf area index ( $\mathrm{LAl})$, tiller leaf:stem ratio and tiller leaf area:volume ratio $(\mathrm{R})$ were calculated. Simple regression analyses between tiller population density and tiller weight were also performed. Coastcross swards showed a tiller size/density compensation mechanism where high tiller population densities were associated with small tillers and vice-versa; except on the last evaluation. However, regression analysis revealed linear coefficients of -3.83 to -2.05 , which are lower than the theoretical expectation of $-3 / 2$. The lower $R$ values observed, when compared to those reported for perennial ryegrass, suggest that Coastcross swards optimised their LAI via clonal integration among tillers in contrast with tillers of cool-season grasses that respond more as individuals. However, this hypothesis has yet to be experimentally verified.
\end{abstract}

Key words: Cynodon, LAl, tiller, morphology

\section{COMPENSAÇÃO TAMANHO/DENSIDADE POPULACIONAL DE PERFILHOS EM PASTAGENS DE CAPIM COASTCROSS}

\begin{abstract}
RESUMO: Vários mecanismos compensatórios em pastagens não permitem a otimização de respostas dos processos determinantes da produção e da utilização de forragem. O mecanismo de compensação tamanho/ densidade é um desses mecanismos. Este experimento avaliou esse processo originalmente descrito para plantas forrageiras de clima temperado. Os tratamentos corresponderam às alturas de pasto de $5,10,15 \mathrm{e}$ $20 \mathrm{~cm}$ mantidas em steady state por ovinos em lotação contínua de Agosto de 1998 a Julho de 1999. O delineamento experimental utilizado foi o de blocos completos ao acaso, com quatro repetições. As respostas avaliadas foram: densidade populacional de perfilhos, massa por perfilho, massa de folhas e área foliar por perfilho e biomassa total. Cálculos de volume por perfilho, índice de área foliar (IAF), relação folha:haste por perfilho e área foliar:volume do perfilho $(R)$ foram executados. Análises de regressão simples entre densidade populacional de perfilhos e peso por perfilho foram também realizadas. As avaliações foram realizadas em dezembro/98, janeiro, abril e julho/99. Pastos de Coastcross apresentaram um mecanismo de compensação tamanho/densidade onde altas densidades populacionais estiveram associadas com perfilhos pequenos e vice-versa, exceto na última avaliação. Contudo, a análise de regressão revelou inclinações de reta que variaram de $-3,83$ a -2,05, superiores à expectativa teórica de -3/2. Em dezembro e janeiro os aumentos em biomassa foram resultado de aumentos em massa por perfilho. Os baixos valores de R observados, quando comparados àqueles determinados para azevém perene, sugerem que pastos de Coastcross otimizem seu IAF via integração clonal entre perfilhos, diferentemente de azevém que operaria através de perfilhos individuais. No entanto, esta hipótese necessita ser comprovada experimentalmente.
\end{abstract}

Palavras-chave: Cynodon, IAF, perfilho, morfologia

\section{INTRODUCTION}

Pastures are characterised by a complex integration of factors that result in very specific and dynamic patterns of responses. In grass swards there are several compensatory mechanisms operating and "buffering" overall responses in terms of herbage production and utilisation. Among these processes, tiller size/population density 
compensation (SDC) is one of the most intriguing mechanisms and has been studied intensively during recent years (Matthew et al., 1995; Sackville Hamilton et al.,1995; Hernández Garay et al., 1999).

In grass plants the vegetative unit is the tiller (Hodgson, 1990). Pastures are a population of single tillers (Mitchell \& Glenday, 1958; Korte, 1986; Colvill \& Marshall, 1984) which implies that increases in herbage production can be generated from increases in tiller numbers, tiller weight or a combination between them (Nelson \& Zarrough, 1981; Bircham \& Hodgson, 1983; Grant et al., 1983; Volenec \& Nelson, 1983). However, tillers are subjected to a SDC mechanism which leads to a small population density of large tillers under lenient defoliation or a high population density of small tillers under intense defoliation (Bircham \& Hodgson, 1983; Grant et al., 1983; Matthew, 1992; Hernández Garay et al., 1999).

Originally, it was supposed that SDC followed the self-thinning rule proposed by Yoda et al. (1963), widely discussed in the literature (White \& Harper, 1970; White; 1980; 1981; 1985; Westoby, 1984), where the relationship between tiller weight and population density (in a $\log \times \log$ scale) followed a linear regression line with slope $-3 / 2$. However, some authors have questioned its universal use for all species (Weller, 1987; 1989; 1990; 1991; Zeide, $1985,1987)$ claiming that not all observations follow the self-thinning dynamics defined by the $-3 / 2$ line. In undefoliated grass swards SDC was observed according to a $-3 / 2$ line, except in situations of low light intensity (Kays \& Harper, 1974; Lonsdale \& Watkinson, 1982). Generally, it has been assumed that swards under grazing also follow this rule (Bircham \& Hodgson, 1983; Lambert et al., 1986; Davies, 1988). On the other hand, visual analysis of data from Davies (1988) suggested a systematic lack of fit to the $-3 / 2$ theoretical line (Sackville Hamilton et al., 1995) and pointed to an inclination steeper than $-3 / 2$, around $-5 /$ 2. Matthew et al., (1995) also observed an inclination steeper than $-3 / 2$ in defoliated perennial ryegrass swards (Lolium perenne L.).

Despite all arguments, Sackville Hamilton et al. (1995) demonstrated that $-3 / 2$ is a theoretical expectation when LAI and leaf area:plant size remain constant. Considering that sward leaf area varies during regrowth or in response to defoliation intensity (Bircham \& Hodgson, 1983; Matthew et al., 1995; Fagundes, 1999), it seems natural that SDC would assume slope values different from $-3 / 2$ in grazed swards. Besides LAI, Sackville Hamilton et al. (1995) demonstrated that adjustments in the $-3 / 2$ line are related to variations in morphogenetic characteristics of tillers in different sward surface heights. As a consequence, these authors developed an index, $R$, that relates leaf area per tiller to tiller volume. This index reflects changes in tiller form as the tiller is submitted to different defoliation intensities independently of tiller size, and accounts for the lack of proportionality between variations in leaf and pseudostem/stem length as tillers get taller.
In order to understand the self-thinning rule and its relationship with the SDC mechanism operating in pastures it is necessary to adjust for variations in LAl (function of the rates of leaf tissue growth and removal) and in $R$ (function of morphogenetic variations in tillers as they adjust to different sward heights) (Matthew et al., 1995). These corrections for LAl and R were proposed by Matthew et al. (1995) and designated $C_{a}$ and $C_{r}$, respectively. These two correction factors are a function of variations in tiller population density as swards are kept short or tall. For perennial ryegrass these two factors accounted for almost all the deviation normally observed between the theoretical SDC slope of $-3 / 2$ and the calculated value from data sets of experiments where grass swards were kept under predefined defoliation regimes (Matthew et al., 1995; Hernández Garay et al., 1999). Matthew et al. (1995) observed inclinations for the self-thinning lines close to $-5 /$ 2 in perennial ryegrass swards with the deviation from the $-3 / 2$ line being explained when $C_{a}$ and $C_{r}$ were considered. The same was true for a data set from Davies (1988), which validated the adjustments for temperate grass species, particularly perennial ryegrass.

A theoretical understanding of the deviations between the observed field values and those of the $-3 / 2$ line has important biological implications. Matthew et al. (1995) suggested that the distance between any point and the $-3 / 2$ theoretical line when plotting tiller weight against tiller population density could represent a sward productivity index since the $-3 / 2$ line defines a situation where LAI is constant (Sackville Hamilton et al., 1995). As a consequence, a longer distance between a given point and the $-3 / 2$ line would indicate a larger dry matter production. This hypothesis was confirmed by a series of experiments in micro swards (Hernández Garay et al., 1999) and field conditions (Bahmani et al., 1998).

The objective of the present experiment was to assess if such a SDC mechanism operates in a prostrate tropical grass species and to study the relationships between tiller weight and population density in grazed swards of 'Coastcross' bermudagrass [Cynodon spp. (L.) Pers.].

\section{MATERIAL AND METHODS}

The experiment was carried out at Unidade Experimental de Plantas Forrageiras (UEPF), Departamento de Produção Animal da E.S.A. "Luiz de Queiroz", Universidade de São Paulo, Piracicaba-SP, Brazil, located at $22^{\circ} 42^{\prime} 30^{\prime \prime}$ south latitude, $47^{\circ} 38^{\prime} 00^{\prime \prime}$ west longitude and $546 \mathrm{~m}$ altitude (Ometto, 1989). Four evaluations were performed throughout the experimental period on the following dates: 15/12/98; 25/01/99; 07/04/ 99 and 04/07/99.

\section{Pastures and experimental period}

The experiment was set up on a Eutric Kandiudalf (Terra Roxa Estruturada) with a high soil fertility level (TABLE 1). No phosphorus fertiliser or lime 
were applied either at pasture establishment or throughout the experimental period. Pastures were first established vegetatively in March 1996, but due to some climatic constraints and poor plant establishment some areas had to be vegetatively replanted during February and March 1997. In 1997 a total of $150 \mathrm{~kg} \mathrm{~N} \mathrm{ha}^{-1}$ was applied as ammonium sulphate. In 1998 pastures received $40 \mathrm{~kg} \mathrm{~N}^{-1}$ as ammonium sulphate in January, July and September, $50 \mathrm{~kg} \mathrm{~N} \mathrm{ha}^{-1}$ on 21 October and 25 $\mathrm{kg} \mathrm{N} \mathrm{ha-1}$ on 7 December. A standard cut was done in March 1998 at $3 \mathrm{~cm}$ from ground level. Sheep were added to experimental units when the target sward surface heights were reached (May). In $1999 \mathrm{~N}$ was applied only twice; 23 February (50 kg N ha-1) and 7 March (75 kg N ha-1). Nitrogen applications and timings were planned to generate enough herbage accumulation to maintain at least two grazing sheep per experimental unit throughout the experimental period (15 December, 1998 to 4 July, 1999).

TABLE 1 - Chemical characteristics of the soil at the experimental site at the commencement of the experiment.

\begin{tabular}{|c|c|c|c|c|c|c|c|c|c|}
\hline $\mathrm{pH}^{*}$ & O.M. & $P$ & $\mathrm{~K}$ & $\mathrm{Ca}$ & $\mathrm{Mg}$ & $\mathrm{H}+\mathrm{Al}$ & SB & $\mathrm{T}$ & V \\
\hline & $\mathrm{g} \mathrm{dm}^{-3}$ & $\mathrm{mg} \mathrm{dm^{-3 }}$ & --- & ---- & $\mathrm{mm}$ & lc $\mathrm{dm}^{-3}$ & ---- & ----- & $\%$ \\
\hline 5,4 & 37,0 & 99 & 4,6 & 75 & 26 & 30 & 106 & 136 & 78,0 \\
\hline
\end{tabular}

\section{Climatic conditions}

According to the Köppen system the climate type of Piracicaba region is Cwa, a humid mesothermic subtropical with a dry winter where the average temperature of the coldest month is lower than $18^{\circ} \mathrm{C}$ and that of the warmest month is higher than $22^{\circ} \mathrm{C}$ (Brasil, 1960). Meteorological figures during the experimental period are presented in TABLE 2.

\section{Experimental design and monitoring of experimental conditions}

Treatments of sward surface height (SSH) were assigned to experimental units, each about $400 \mathrm{~m}^{2}$, according to a randomised complete block design with four replications. The bermudagrass cultivar was allowed to grow to the desired surface heights of $5,10,15$ or 20 $\mathrm{cm}$, after which swards were maintained at that height from August 1998 until July 1999 through continuous stocking by sheep with variable stocking rate (Figure 1). The average SSH was monitored through 20 rising plate meter readings (RPMR) per experimental unit twice a week. A corresponding sward stick height was also recorded. Once a month a calibration equation between RPMR and its correspondent sward stick height was generated, giving the values of sward height (uncompressed SSH) used as reference to monitor the experimental treatments. Grazing sheep were either added or removed from the experimental units as swards

TABLE 2 - Average monthly air temperatures (maximum, minimum and mean), rainfall and sunshine hours throughout the experimental period (November/98 - July/99) and comparison with the 80 years average.

\begin{tabular}{|c|c|c|c|c|c|}
\hline \multirow{2}{*}{ Month/year } & \multicolumn{3}{|c|}{ Temperature } & \multirow{2}{*}{ Rainfall } & \multirow{2}{*}{$\begin{array}{l}\text { Sunshin } \\
\text { hours }\end{array}$} \\
\hline & Maximum & Minimum & Mean & & \\
\hline & -------------- & $-{ }^{\circ} \mathrm{C}-$ & - & $\mathrm{mm}$ & $\mathrm{h}_{\mathrm{day}}{ }^{1}$ \\
\hline November/98 & 30,0 & 16,5 & 23,2 & 27 & 7,8 \\
\hline Mean ( 80 years - Nove mber) & 29,6 & 16,7 & 23,1 & 130 & 7,4 \\
\hline December/98 & 30,0 & 19,2 & 24,6 & 293 & 6,1 \\
\hline Mean (80 years - December) & 29,6 & 18,2 & 23,9 & 200 & 6,6 \\
\hline January/99 & 31,4 & 19,0 & 25,2 & 211 & 7,7 \\
\hline Mean (80 years - January) & 30,0 & 18,2 & 24,1 & 142 & 6,8 \\
\hline February/99 & 30,7 & 20,1 & 25,4 & 198 & 5,4 \\
\hline Mean (80 years - February) & 30,2 & 19,0 & 24,6 & 186 & 6,5 \\
\hline March/99 & 31,4 & 19,0 & 25,2 & 211 & 7,7 \\
\hline Mean ( 80 years - March) & 30,0 & 18,2 & 24,1 & 142 & 6,8 \\
\hline April/99 & 28,5 & 15,2 & 21,9 & 89 & 8,1 \\
\hline Mean (80 years - April) & 28,3 & 15,4 & 21,8 & 65 & 7,5 \\
\hline May/99 & 25,4 & 11,2 & 18,3 & 51 & 7,5 \\
\hline Mean (80 years - May) & 26,1 & 12,1 & 19,1 & 53 & 7,3 \\
\hline June/99 & 23,9 & 11,0 & 17,5 & 69 & 6,0 \\
\hline Mean (80 years - June) & 24,9 & 10,3 & 17,6 & 44 & 7,1 \\
\hline July/99 & 26,4 & 12,0 & 19,2 & 3 & 6,7 \\
\hline Mean (80 years - July) & 25,3 & 9,5 & 17,4 & 27 & 7,9 \\
\hline
\end{tabular}

Source: Departamento de Ciências Exatas Files - ESALQ/USP (1999) 
were $20 \%$ above or below target SSH, respectively, two to three times a week. Plate readings were used preferably because they were fast and allowed for optimisation of time and labour.

\section{Assessment of the tiller size/population density parameters}

All measurements related to individual tiller traits were made in an $8.5 \times 14.7 \mathrm{~cm}$ quadrat $(0.0125$ $\mathrm{m}^{2}$ ). Quadrats were placed on sites presenting the target $\mathrm{SSH}$ for a given treatment and two samples per replicate were cut to ground level from each experimental unit using scissors and a razor. Despite the frequency and fairly homogeneous state of swards, particularly short ones, there was some degree of variability across paddocks in terms of SSH. As measurements were related to a set of sward state conditions, sampling areas were previously chosen by using a sward stick to place quadrats on sites presenting the target SSH accordingly. The cut material was placed in plastic bags previously wetted and conditioned in a Styrofoam box with ice to reduce plant dehydration and respiration. All samples were taken to the laboratory and stored in a cold room.

\section{Biomass}

For biomass evaluation ( $\mathrm{kg} \mathrm{DM} \mathrm{m}^{-2}$ ) two $0.25 \mathrm{~m}^{2}$ quadrats were used per experimental unit. Quadrats were placed on sites presenting the target SSH for treatments and the herbage mass within them was cut to ground level by electric sheep shears. Samples were conditioned in plastic bags and stored in a cold room. Each sample was washed to remove soil and dung contamination and dried in a forced draught oven at $65^{\circ} \mathrm{C}$ for 48 hours prior to weighing.

Fresh and dry weight, leaf area and leaf mass per tiller

Twenty of the cut tillers were selected at random from the $8.5 \times 14.7 \mathrm{~cm}$ quadrat samples. These were weighed and the average fresh weight per tiller (TFW) calculated. After weighing, all green leaf lamina were detached from the tiller axis and had their area measured

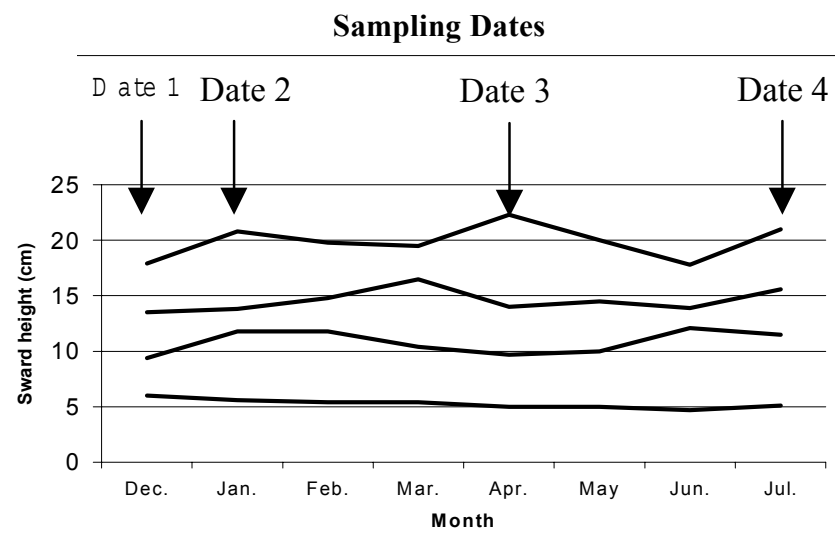

Figure 1 - Average sward surface height maintained throughout the experimental period. Sampling dates are indicated.
(LI-3100, LICOR). Values were used to calculate the average leaf area per tiller (LAT). Leaf laminas were then placed into small paper bags and dried in a forced draught oven at $65^{\circ} \mathrm{C}$ for 48 hours. The same procedure was performed for the combined stem and senescent leaf material. After drying, samples were weighed and the average dry weight live lamina (LW) and stem/ senescent material (SSM) per tiller was calculated. Total dry weight per tiller (TW) was calculated as the sum of LW and SSM.

\section{Tiller population density (TPD)} calculation:

TPD was obtained through the following

$$
T P D=\frac{H M\left(\mathrm{~kg} \mathrm{~m}^{-2}\right)}{T W(\mathrm{~kg})}
$$

where: $\mathrm{HM}=$ herbage mass (biomass) and $\mathrm{TW}=$ tiller weight.

Leaf area index (LAI)

Sward LAI was determined according to the following calculation:

$$
L A I=T P D \times L A T \text { where: }
$$

TPD $=$ tiller population density $\left(\right.$ tillers $\mathrm{m}^{-2}$ ) and LAT = leaf area per tiller $\left(\mathrm{m}^{2}\right.$ tiller $\left.^{-1}\right)$.

\section{Tiller volume}

Average tiller volume was estimated by a technique based on the immersion of tillers in liquids with known apparent densities. Water $\left(1000 \mathrm{~kg} \mathrm{~m}^{-3}\right)$ and a lubricant oil $\left(902 \mathrm{~kg} \mathrm{~m}^{-3}\right.$ at $\left.20^{\circ} \mathrm{C}\right)$ were used as references. Tillers floated in water but sank in oil, so it was assumed that tiller apparent density (TAD) was around $950 \mathrm{~kg} \mathrm{~m}^{-3}$. The estimated value proved to be quite robust since variations in actual densities would generate a $5 \%$ maximum variability in the final estimates of tiller volume. So, the average volume per tiller (TV) was calculated as:

$$
T V\left(m^{3}\right)=\frac{T F W}{T A D},
$$

where: $\mathrm{TFW}=$ tiller fresh weight $(\mathrm{kg})$ and $\mathrm{TAD}=$ tiller apparent density $\left(950 \mathrm{~kg} \mathrm{~m}^{-3}\right)$.

\section{Tiller leaf area:volume ratio (R)}

The tiller leaf area:volume ratio proposed by Sackville Hamilton et al. (1995) was calculated as:

$$
R=\frac{L A T^{3 / 2}}{T V}, \text { where: }
$$

LAT $=$ leaf area per tiller $\left(\mathrm{m}^{2}\right)$, where LAT is powered at $3 / 2$ to allow for an adimensional value (Sackvillle Hamilton et al., 1995) and TV = tiller volume $\left(\mathrm{m}^{3}\right)$. 
Regressions log (TPD) x log(TW)

Linear regressions based on Ordinary Least Square (OLS) between TPD and TW were generated using treatment means, which corresponded to four sets of paired data for each evaluation date. Following the procedure described by LaBarbera (1989), cited by Sackville Hamilton et al. (1995), slopes generated by OLS were divided by the correlation between log (TPD) and log (TW) resulting in the Reduced Major Axis (RMA) slopes, which were used for treatment comparisons.

$C_{a}$ and $C_{r}$ and the distance between observed points and the theoretical $-3 / 2$ line

Estimates of the correction factors for the deviations between the actual regression lines and the $3 / 2$ line for each sample data were made according to Matthew et al. (1995):

$$
C_{a}=\frac{\Delta \log \left(L A l^{3 / 2}\right)}{\Delta \log (T P D)} \text { and } C_{r}=\frac{\Delta \log (R)}{\Delta \log (T P D)},
$$

where: $\mathrm{LAI}=$ sward leaf area index; TPD = tiller population density $\left(\mathrm{n}^{\circ} / \mathrm{m}^{2}\right)$ and $\mathrm{R}=$ tiller leaf area:volume ratio.

$\mathrm{C}_{\mathrm{a}}$ and $\mathrm{C}_{r}$ were calculated as being the slopes for the regressions between sward LAI and TPD and R and TPD, respectively. According to Matthew et al. (1995), the distance between any given point and the $-3 / 2$ line placed below the plotted points can be used as a sward productivity index. In this experiment the perpendicular distance between the plotted points for log (TPD) $\times \log$ (TW) and the $-3 / 2$ line (constant LAl and R) was calculated.

\section{Statistical analysis}

Data were analysed using PROC GLM (General Linear Models) and PROC REG from the statistical package SAS (Statistical Analysis System). Analysis of variance was performed using the Repeated Measures option since all variables were measured sequentially throughout the experimental period (SAS Institute, 1988). All data sets were tested for normality and homogeneity of variances prior to the general analysis, and comparisons between treatment means were performed using LSMEANS.

\section{RESULTS AND DISCUSSION}

Statistical analysis showed effects of evaluation date and SSH for TW, LW, TV, LAT, biomass and tiller leaf:stem ratio (all at $\mathrm{P}<0.10$ ). There was a evaluation date effect and a evaluation date $\times \mathrm{SSH}$ interaction for TPD, and a SSH effect for R and LAI (all at $P<0.10$ ).

\section{Tiller population density}

There was a steady increase in TPD from evaluation date 1 to evaluation date 3 (TABLE 3), when values stabilised. The smaller TPD observed in date 1 was probably a consequence of the dry spell observed in November (TABLE 2). In December, when rainfall returned to normal, TPD increased. Despite no SSH effect, there was a trend for tall swards to present lower TPD than short swards at evaluation dates 1 and 2 . These results are in agreement with data generated from temperate forages, where higher TPD were associated with swards kept short (Bircham \& Hodgson, 1983; Matthew et al., 1995; Hernández Garay et al., 1999). Conversely, swards maintained at $10 \mathrm{~cm}$ during evaluation 3 presented a TPD higher than those kept at $5 \mathrm{~cm}$, indicating that Coastcross swards were not able to compensate the reduced SSH by increasing tiller numbers. Hernández Garay et al. (1999) and Bircham \& Hodgson (1983) reported a similar situation for perennial ryegrass where frequent defoliation resulted in lower TPD for their most severe defoliation treatment. This situation fits into a theoretical condition described by Matthew et al. (1995) where a high defoliation intensity can, under certain circumstances, restrict tillering activity in grass plants.

On date 4, a reverse trend of increasing TPD with increasing swards surface height over the $10 \mathrm{~cm}$ to 20 $\mathrm{cm}$ height range was observed. This observation is explained the formation, on higher cutting heights, of crowns containing numerous small tillers, and originated from the nodes of decapitated reproductive stems (Carnevalli \& Da Silva, 1999).

\section{Tiller dry weight, leaf mass and volume}

The highest values of TW were observed on evaluation date 1 , with values decreasing as the season progressed (TABLE 4). The same happened for LW and TV (TABLES 5 and 6), a likely consequence of the low rainfall observed in November (TABLE 2), since other growth factors such as light, mineral nutrients and temperature appeared adequate, and plants probably continued to accumulate nutrients via photosynthesis but did not generate growth compatible with that accumulation. Furthermore, there was an increase in TW, LW and TV as SSH increased from 5 to $20 \mathrm{~cm}$ (TABLES 4,5 and 6 ). These results corroborate those reported for temperate forage plants where taller swards also presented the higher values for leaf mass per tiller, TW (Matthew et al., 1995; Hernández Garay et al., 1999) and TV (Matthew et al., 1995) than shorter ones.

TABLE 3 - Tiller population density for the sward surface heights (SSH) studied.

\begin{tabular}{|c|c|c|c|c|c|}
\hline \multirow{2}{*}{ SSH } & \multicolumn{4}{|c|}{ Evaluation date } & \multirow{2}{*}{ Mean } \\
\hline & 1 & 2 & 3 & 4 & \\
\hline $\mathrm{cm}$ & \multicolumn{5}{|c|}{ - } \\
\hline 5 & $15127 a$ & $16482 a$ & $11155 a$ & $14415 a b$ & 14295 \\
\hline 10 & $9904 b$ & 11773ab & $15528 a$ & $11661 b$ & 12217 \\
\hline 15 & $10145 b$ & $9026 b$ & $14483 a$ & $12001 b$ & 11414 \\
\hline 20 & $6980 c$ & $9996 b$ & $12251 \mathrm{a}$ & $17659 a$ & 11722 \\
\hline Mean & 10539 & 11819 & 13354 & 13934 & \\
\hline SEM $^{*}$ & 1347 & 2645 & 1730 & 2220 & \\
\hline
\end{tabular}

*SEM - Standard error of the mean. Similar letters in the same column do not differ $(P>0,10)$. Date $1=15$ Dec 1998, Date $2=25$ Jan 1999, Date $3=07$ Apr 1999, Date $4=04$ Jul 1999. 


\section{Biomass}

Biomass yields on dates 1 and 4 were higher than those on dates 2 and 3 (TABLE 7). An increase in biomass was observed with increasing SSH. TPD has often been used as a measure of sward vigour and productivity (Binnie \& Chestnut, 1991; Thom \& Bryant, 1993). Some studies, however, have demonstrated the

TABLE 4 - Average tiller weight for the sward surface heights (SSH) studied.

\begin{tabular}{|c|c|c|c|c|c|}
\hline \multirow{2}{*}{ SSH } & \multicolumn{4}{|c|}{ Evaluation Date } & \multirow{2}{*}{ Mean } \\
\hline & 1 & 2 & 3 & 4 & \\
\hline $\mathrm{cm}$ & \multicolumn{5}{|c|}{ - } \\
\hline 5 & $17,4 \mathrm{c}$ & $11,1 \mathrm{c}$ & $17,4 \mathrm{~b}$ & $17,8 \mathrm{~b}$ & 15,9 \\
\hline 10 & $41,2 b$ & $32,6 \mathrm{bc}$ & $22,6 \mathrm{~b}$ & $36,7 \mathrm{a}$ & 33,3 \\
\hline 15 & $51,1 \mathrm{~b}$ & $43,2 \mathrm{ab}$ & $28,4 \mathrm{~b}$ & $41,5 \mathrm{a}$ & 41,0 \\
\hline 20 & $88,8 \mathrm{a}$ & 63,0 a & 55,6 a & $42,8 \mathrm{a}$ & 62,5 \\
\hline Mean & 49,7 & 37,4 & 31,0 & 34,7 & \\
\hline SEM $^{*}$ & 5,9 & 8,9 & 8,1 & 7,0 & \\
\hline
\end{tabular}

${ }^{*}$ SEM - Standard error of the mean. Similar letters in the same column do not differ $(P>0,10)$. Date $1=15$ Dec 1998, Date $2=25$ Jan 1999, Date 3 = 07 Apr 1999, Date 4 = 04 Jul 1999.

TABLE 5 - Average leaf lamina mass for the sward surface heights (SSH) studied.

\begin{tabular}{|c|c|c|c|c|c|}
\hline \multirow{2}{*}{ SSH } & \multicolumn{4}{|c|}{ Evaluation date } & \multirow{2}{*}{ Mean } \\
\hline & 1 & 2 & 3 & 4 & \\
\hline $\mathrm{cm}$ & ---------- & -----------. & mg ----. & ---------- & ------ \\
\hline 5 & $8,0 \mathrm{c}$ & $5,90 \mathrm{c}$ & $6,8 \mathrm{~b}$ & $9,3 \mathrm{~b}$ & 7,5 \\
\hline 10 & $18,7 \mathrm{~b}$ & $13,5 \mathrm{bc}$ & $8,9 \mathrm{~b}$ & $11,7 \mathrm{~b}$ & 13,2 \\
\hline 15 & $20,1 \mathrm{ab}$ & $18,9 a b$ & $9,4 \mathrm{~b}$ & $13,1 \mathrm{ab}$ & 15,4 \\
\hline 20 & 29,9 a & $24,5 \mathrm{a}$ & $16,4 \mathrm{a}$ & $16,7 \mathrm{a}$ & 21,9 \\
\hline Mean & 19,2 & 15,7 & 10,4 & 12,7 & \\
\hline SEM $^{*}$ & 2,7 & 4,1 & 1,3 & 1,8 & \\
\hline
\end{tabular}

*SEM - Standard error of the mean. Similar letters in the same column do not differ $(P>0,10)$. Date $1=15$ Dec 1998, Date $2=25$ Jan 1999, Date $3=07$ Apr 1999, Date $4=04$ Jul 1999.

TABLE 6 - Average tiller volume for the sward surface heights (SSH) studied.

\begin{tabular}{|c|c|c|c|c|c|}
\hline \multirow{2}{*}{ SSH } & \multicolumn{4}{|c|}{ Evaluation date } & \multirow{2}{*}{ Mean } \\
\hline & 1 & 2 & 3 & 4 & \\
\hline $\mathrm{cm}$ & \multicolumn{5}{|c|}{ [-- } \\
\hline 5 & $0,102 \mathrm{c}$ & $0,065 \mathrm{c}$ & $0,101 \mathrm{~b}$ & $0,104 \mathrm{a}$ & 0,093 \\
\hline 10 & $0,241 \mathrm{~b}$ & $0,191 \mathrm{bc}$ & $0,132 \mathrm{~b}$ & $0,215 b$ & 0,195 \\
\hline 15 & $0,298 \mathrm{~b}$ & $0,253 a b$ & $0,166 \mathrm{~b}$ & $0,243 b$ & 0,240 \\
\hline 20 & $0,519 a$ & 0,368 a & $0,325 \mathrm{a}$ & $0,250 \mathrm{~b}$ & 0,366 \\
\hline Mean & 0,290 & 0,219 & 0,181 & 0,203 & \\
\hline SEM $^{*}$ & 0,0346 & 0,0521 & 0,0474 & 0,0409 & \\
\hline
\end{tabular}

*SEM - Standard error of the mean. Similar letters in the same column do not differ $(P>0,10)$. Date $1=15$ Dec 1998, Date $2=25$ Jan 1999, Date 3 = 07 Apr 1999, Date $4=04$ Jul 1999. importance of the interaction between TPD and TW as determinants of productivity (Langer, 1979; Bircham \& Hodgson, 1983). It has been considered that tiller formation is more important when TPD is low (Nelson \& Zarrough, 1981; Volenec \& Nelson, 1983). This situation was verified on sampling dates 3 and 4 in the present experiment. On date 3 the increase in TW between 5 and $10 \mathrm{~cm}$ swards was about $30 \%$ while on dates 1 and 2 it was more than 100\% (TABLE 4). On those dates, however, herbage biomass increased about $52 \%$, demonstrating that increments in biomass were greatly influenced by TPD, which increased $39 \%$ between 5 and $10 \mathrm{~cm}$ swards on date 3 (TABLE 3). On date 4, TW increased only $3 \%$ from 15 to $20 \mathrm{~cm}$ swards (TABLE 4) and biomass showed a corresponding increase of around $53 \%$ (TABLE 7), which resulted from the $47 \%$ increase in TPD (TABLE 3). On the other hand, factors determining increases in biomass on dates 1 and 2 were related to TW, since a reduction in TPD was observed as SSH increased. Volenec \& Nelson (1983) recognised that TW could be more important than TPD in determining sward productivity under certain circumstances.

\section{Leaf area per tiller and sward leaf area index}

The highest values of LAT were observed on dates 1 and 2 (TABLE 8) but there was no time effect for sward LAI (TABLE 9). Matthew at al. (1999) noted that $\mathrm{LAl}$ is determined by three components: tiller population density, number of live leaves per tiller and mean area of live leaf lamina. The number of live leaves per tiller is relatively constant for a given grass species or cultivar (Davies, 1977; Yang et al., 1998; Carnevalli \& Da Silva, 1999). Leaf lamina area of grasses depends greatly on leaf lamina length, which is a function of defoliation intensity. As a consequence, TPD is the LAI component that allows for a greater flexibility of plants to adjust to different defoliation regimes and is the reason why LAI is optimised in hard-grazed swards through a high TPD of small tillers. Conversely, in lax-grazed swards optimisation of LAl is achieved through a lower TPD of larger tillers (Matthew et al., 1999). Despite the highest values of LAT being observed on dates 1 and 2, LAI did not vary accordingly. This happened because TPD had a major role in determining sward LAI, showing a tendency to increase over time and compensate the decrease in LAT (TABLES 3, 8 and 9).

\section{Tiller leaf:stem and tiller leaf area:volume (R) ratios}

Tiller leaf:stem ratio decreased as $\mathrm{SSH}$ increased, with the lowest ratios measured on date 3 (TABLE 10). Tiller leaf area:volume ratio (R) varied slightly throughout the experimental period. Tillers of similar shape subjected to differing rates of leaf removal, can be expected to have a higher $\mathrm{R}$ with higher sward heights (lower $\mathrm{R}$ with lower sward heights) (Matthew et al., 1995; Hernandez Garay et al., 1999). Such an effect was seen on date 2 (TABLE 11). As swards matured, 
sward structure changed. By date 4 tillers in 10 to $15 \mathrm{~cm}$ swards had developed distinct stems (and showed a lower R) while many tillers in $20 \mathrm{~cm}$ swards had 'rosetas' of small, leafy tillers, which increased the mean $R$ value for the sward as a whole. The tiller leaf area:volume ratio (R) was originally proposed by Sackville Hamilton et al. (1995) and its calculation uses LAT powered at $3 / 2$ as a means of allowing for an adimensional value. According to Hernández Garay et al. (1999), measurements of tiller

TABLE 7 - Total aerial biomass for the sward surface heights (SSH) studied.

\begin{tabular}{|c|c|c|c|c|c|}
\hline \multirow{2}{*}{ SSH } & \multicolumn{4}{|c|}{ Evaluation date } & \multirow{2}{*}{ Mean } \\
\hline & 1 & 2 & 3 & 4 & \\
\hline $\mathrm{cm}$ & \multicolumn{5}{|c|}{ - } \\
\hline 5 & $0,28 d$ & $0,16 \mathrm{~d}$ & $0,21 \mathrm{c}$ & $0,26 \mathrm{c}$ & 0,23 \\
\hline 10 & $0,39 \mathrm{c}$ & $0,33 \mathrm{c}$ & $0,32 \mathrm{~b}$ & $0,35 \mathrm{bc}$ & 0,35 \\
\hline 15 & $0,50 \mathrm{~b}$ & $0,37 \mathrm{~b}$ & $0,38 \mathrm{~b}$ & $0,47 \mathrm{~b}$ & 0,43 \\
\hline 20 & $0,60 a$ & $0,55 a$ & $0,57 \mathrm{a}$ & $0,72 \mathrm{a}$ & 0,61 \\
\hline Mean & 0,44 & 0,35 & 0,37 & 0,45 & \\
\hline SEM $^{*}$ & 0,03 & 0,02 & 0,03 & 0,05 & \\
\hline
\end{tabular}

*SEM - Standard error of the mean. Similar letters in the same column do not differ $(P>0,10)$. Date $1=15$ Dec 1998, Date $2=25$ Jan 1999, Date 3 = 07 Apr 1999, Date 4 = 04 Jul 1999.

TABLE 8 - Average leaf area per tiller for the sward surface heights (SSH) studied.

\begin{tabular}{|c|c|c|c|c|c|}
\hline \multirow{2}{*}{ SSH } & \multicolumn{4}{|c|}{ Evaluation date } & \multirow{2}{*}{ Mean } \\
\hline & 1 & 2 & 3 & 4 & \\
\hline $\mathrm{cm}$ & \multicolumn{5}{|c|}{ - } \\
\hline 5 & $1,26 \mathrm{c}$ & $1,25 b$ & $0,82 \mathrm{c}$ & $1,15 b$ & 1,12 \\
\hline 10 & $2,57 \mathrm{~b}$ & $2,12 \mathrm{~b}$ & $1,48 \mathrm{~b}$ & $1,74 \mathrm{~b}$ & 1,98 \\
\hline 15 & $2,64 b$ & $2,67 a b$ & $1,39 \mathrm{~b}$ & $1,78 b$ & 2,12 \\
\hline 20 & 3,85 a & $3,57 \mathrm{a}$ & $2,41 \mathrm{a}$ & $2,83 a$ & 3,17 \\
\hline Mean & 2,58 & 2,40 & 1,53 & 1,88 & \\
\hline SEM $^{*}$ & 0,35 & 0,6 & 0,21 & 0,32 & \\
\hline
\end{tabular}

*SEM - Standard error of the mean. Similar letters in the same column do not differ $(P>0,10)$. Date $1=15$ Dec 1998, Date $2=25$ Jan 1999, Date 3 = 07 Apr 1999, Date 4 = 04 Jul 1999.

TABLE 9 - Sward leaf area index (LAI) for the sward surface heights studied (SSH).

\begin{tabular}{lccccc}
\hline \multirow{5}{*}{ SSH } & \multicolumn{5}{c}{ Evaluation date } \\
\cline { 2 - 5 } & 1 & 2 & 3 & 4 & \\
\hline $\mathrm{cm}$ & & & & & \\
5 & $1,75 \mathrm{~b}$ & $1,39 \mathrm{~b}$ & $1,25 \mathrm{c}$ & $2,14 \mathrm{~b}$ & 1,63 \\
10 & $2,43 \mathrm{a}$ & $2,16 \mathrm{~b}$ & $2,24 \mathrm{~b}$ & $2,08 \mathrm{~b}$ & 2,23 \\
15 & $2,63 \mathrm{a}$ & $2,32 \mathrm{~b}$ & $1,99 \mathrm{~b}$ & $2,03 \mathrm{~b}$ & 2,24 \\
20 & $2,55 \mathrm{a}$ & $3,16 \mathrm{a}$ & $2,81 \mathrm{a}$ & $4,77 \mathrm{a}$ & 3,32 \\
\hline Mean & 2,34 & 2,26 & 2,07 & 2,76 & \\
SEM $^{*}$ & 0,22 & 0,19 & 0,33 & 0,55 & \\
\hline
\end{tabular}

*SEM - Standard error of the mean. Similar letters in the same column do not differ $(P>0,10)$. Date $1=15$ Dec 1998, Date $2=25$ Jan 1999, Date 3 = 07 Apr 1999, Date 4 = 04 Jul 1999. leaf:stem ratio are inadequate to estimate parameters related to SDC since leaf and stem are plant components that possess different dimensions that are ignored by the simple calculation based on mass $(\mathrm{kg})$. So, increases in SSH can consistently lead to decreased leaf:stem ratios simply by the fact that in order to endure the weight of leaves the diameter of stems is altered in direct proportion of the force required to support them and not isometrically to the organ weight (McMahon, 1973; McMahon \& Kronauer, 1976; Niklas, 1994).

Despite some variation in $\mathrm{R}$ values, they were not different statistically with the overall mean value around 15 (TABLE 11). Hernandez Garay et al. (1999) reported $R$ values around 50 for perennial ryegrass and these became higher as $\mathrm{SSH}$ increased, indicating that perennial ryegrass grew by developing more leaf area than stem length per tiller. Matthew et al. (1995) discussed that inter-specific variations in $\mathrm{R}$ could have some ecological implications. According to those authors, plants presenting high values of $R$ would have a better competitive ability than plants characterised by low $R$ values, an indication of higher individual tiller capacity to pre-emptively capture light in plant communities. On the other hand, low values of $R$ could represent a morphological adaptation towards diminishing the damaging effects of water loss by plants.

One possible reason for the lower values of $R$ observed in this experiment relative to those found in the literature for perennial ryegrass could be the existence of a clonal integration pattern among Cynodon tillers. Matthew et al. (1995) showed that $R$ values in alfalfa (Medicago sativa L.) (plant with a high degree of integration among shoots since they are all generated from a common crown) were higher when calculations were based on the whole plant rather than on single shoots by a factor of $n^{1 / 2}$, where $n$ is the number of shoots per crown, indicating that integration is more closely associated with coordinated flushes of development among associated shoots. Coastcross bermudagrass seems to have the same behaviour.

TABLE 12 presents $R$ values assuming an hypothetical clonal integration among four tillers for Coastcross. According to those numbers, $R$ values increased two-fold in all situations and became very close to those values reported by Hernández Garay et al. (1999) for perennial ryegrass. This would suggest that a functional equivalent to having a reduced stem size as a competitive strategy (reduction of sink biomass) is to have clonal integration; and Cynodon tillers use such a strategy. This is in agreement with field observations that a new cluster of tillers is formed along a stolon at regular intervals of three phytomers (leaves) (node with roots and a daughter tiller followed by two successive leaves) (PLATE 1). This structure suggests that one leaf would support root development, a second would support tiller development and a third would support stolon internode elongation. 
Another consequence of this strategy is that Coastcross pastures could acquire competitive advantage through clonal integration of tillers. Similar behaviour has not been described in the literature for perennial ryegrass plants, suggesting that those individual plants may operate as discrete units rather than groups. However, further studies under controlled experimental conditions and planned accordingly will be

TABLE 10 - Tiller leaf:stem ratio for the sward surface heights (SSH) studied.

\begin{tabular}{llllll}
\hline \multirow{2}{*}{ SSH } & \multicolumn{5}{c}{ Evaluation date } \\
\cline { 2 - 5 } & 1 & 2 & 3 & 4 & \\
\hline $\mathrm{cm}$ & & & & & \\
\hline 5 & $0,88 \mathrm{a}$ & $1,04 \mathrm{a}$ & $0,71 \mathrm{a}$ & $1,17 \mathrm{a}$ & 0,95 \\
10 & $0,90 \mathrm{a}$ & $0,81 \mathrm{~b}$ & $0,79 \mathrm{a}$ & $0,72 \mathrm{~b}$ & 0,81 \\
15 & $0,69 \mathrm{~b}$ & $0,80 \mathrm{~b}$ & $0,64 \mathrm{a}$ & $0,63 \mathrm{~b}$ & 0,69 \\
20 & $0,65 \mathrm{~b}$ & $0,78 \mathrm{~b}$ & $0,48 \mathrm{a}$ & $0,69 \mathrm{~b}$ & 0,65 \\
\hline Mean & 0,78 & 0,86 & 0,65 & 0,80 & \\
SEM $^{*}$ & 0,07 & 0,07 & 0,16 & 0,13 & \\
\hline
\end{tabular}

${ }^{*}$ SEM - Standard error of the mean. Similar letters in the same column do not differ $(P>0,10)$. Date $1=15$ Dec 1998, Date $2=25$ Jan 1999, Date 3 = 07 Apr 1999, Date $4=04$ Jul 1999.

TABLE 11 - Tiller leaf area:volume ratio $(R)$ for the sward surface heights $(\mathrm{SSH})$ studied.

\begin{tabular}{lccccc}
\hline \multirow{5}{*}{ SSH } & \multicolumn{5}{c}{ Evaluation date } \\
\cline { 2 - 5 } & 1 & 2 & 3 & 4 & \\
\hline $\mathrm{cm}$ & & & & & \\
5 & $11,7 \mathrm{~b}$ & $13,4 \mathrm{a}$ & $10,7 \mathrm{a}$ & $18,1 \mathrm{a}$ & 13,5 \\
10 & $17,0 \mathrm{a}$ & $16,2 \mathrm{a}$ & $14,4 \mathrm{a}$ & $12,7 \mathrm{ab}$ & 15,1 \\
15 & $14,4 \mathrm{ab}$ & $17,3 \mathrm{a}$ & $10,7 \mathrm{a}$ & $9,8 \mathrm{~b}$ & 13,0 \\
20 & $14,3 \mathrm{ab}$ & $18,7 \mathrm{a}$ & $12,6 \mathrm{a}$ & $19,0 \mathrm{a}$ & 16,2 \\
\hline Mean & 14,4 & 16,4 & 12,1 & 14,9 & \\
SEM $^{*}$ & 1,5 & 3,3 & 2,0 & 2,7 & \\
\hline
\end{tabular}

*SEM - Standard error of the mean. Similar letters in the same column do not differ $(P>0,10)$. Date $1=15$ Dec 1998, Date $2=25$ Jan 1999, Date $3=07$ Apr 1999, Date $4=04$ Jul 1999.

TABLE 12 - Tiller leaf area:volume ratio $(R)$ assuming a clonal integration of four tillers for the sward surface heights (SSH) studied.

\begin{tabular}{lccccc}
\hline \multirow{2}{*}{ SSH } & \multicolumn{5}{c}{ Evaluation date } \\
\cline { 2 - 5 } & 1 & 2 & 3 & 4 & \\
\hline $\mathrm{cm}$ & & & & & \\
5 & $23,4 \mathrm{~b}$ & $26,9 \mathrm{a}$ & $21,4 \mathrm{a}$ & $36,2 \mathrm{a}$ & 27,0 \\
10 & $34,1 \mathrm{a}$ & $32,3 \mathrm{a}$ & $29,0 \mathrm{a}$ & $25,3 \mathrm{ab}$ & 30,2 \\
15 & $28,8 \mathrm{ab}$ & $34,5 \mathrm{a}$ & $21,3 \mathrm{a}$ & $19,6 \mathrm{~b}$ & 26,1 \\
20 & $28,7 \mathrm{ab}$ & $37,5 \mathrm{a}$ & $25,2 \mathrm{a}$ & $38,0 \mathrm{a}$ & 32,3 \\
\hline Mean $^{2}$ & 28,7 & 32,8 & 24,3 & 29,8 & \\
SEM $^{*}$ & 2,9 & 6,6 & 4,0 & 5,3 & \\
\hline
\end{tabular}

*SEM - Standard error of the mean. Similar letters in the same column do not differ $(P>0,10)$. Date $1=15$ Dec 1998, Date $2=25$ Jan 1999, Date 3 = 07 Apr 1999, Date $4=04$ Jul 1999. necessary to elucidate the degree and the nature of this integration in order to allow for a better understanding of plant persistence, competitive ability and productivity.

\section{Functional relationship between tiller weight and tiller population density}

Simple regression analysis performed on data for dates 1,2 and 3 revealed the functional relationships presented in TABLE 13. Data from the evaluation for date 4 could not be used due to "rosetas" formation that inflated the TPD values (TABLE 3). The generated slopes $\left(b_{1}\right)$ were steeper than the theoretical expectation of $-3 /$ 2 (Figure 2 and TABLE 13). According to Sackville Hamilton et al. (1995), a -3/2 line would be a theoretical expectation when LAI and $R$ remained constant. Since LAI of Coastcross bermudagrass varied with different SSH (TABLE 9), it would be expected that the slopes observed were different from $-3 / 2$. Hernandez Garay et al. (1999) also observed slopes steeper than $-3 / 2$ (close to $-5 / 2$ ) for perennial ryegrass swards.

The correction factors $\mathrm{C}_{\mathrm{a}}$ and $\mathrm{C}_{\mathrm{r}}$ proved to be effective in accounting for deviations between slope lines in evaluation dates 1 and 2 . One of the main factors that could have influenced the discrepancy between the observed slope and the value predicted by $C_{a}$ and $C_{r}$ in evaluation date 3 would have been the effect of canopy size on reproductive growth of Coastcross swards, where $\mathrm{SSH}$ treatments went into flowering at different times. This could have modified sward structure and affected the key variables used for predicting the slopes: TPD, TV and LAT (TABLES 3, 6 and 8).

Despite these limitations, estimated values for $\mathrm{C}_{\mathrm{a}}$ were higher than those for $C_{r}$, indicating that in Coastcross pastures the variation in LAl is the main factor determining the tiller size/density compensation, similar to perennial ryegrass swards (Matthew et al., 1999; Hernández Garay et al., 1999). The variation in $R$ is a comparatively minor element of plant growth strategy in the vegetative phase, but $R$ does fall in reproductive phase, allowing the sward to accommodate greater TPD than would otherwise have been the case. This is similar to Lolium perenne (Matthew et al., 1995) but not necessarily true for all grasses.

\section{Practical implications}

Matthew et al. (1995) suggested that the distance between any given point defined by its co-ordinates TW and TPD (in a log scale) and the $-3 / 2$ theoretical line could have a value as a sward productivity index. As demonstrated by Sackville Hamilton et al. (1995), the $3 / 2$ line defines a situation where LAI is constant. It follows that the greater the distance between the observed points and the $-3 / 2$ line the larger the LAI and, consequently, the greater the sward capacity in accumulate herbage dry matter. This hypothesis was confirmed for temperate forage plants in micro swards (Hernández Garay et al., 1999) and in field conditions (Bahmani et al., 1998). 
TABLE 13 - Linear coefficients $\left(\beta_{0}\right)$, intercepts $\left(\beta_{1}\right)$, determination coefficients $\left(r^{2}\right)$ and levels of significance for the $\log _{10} x$ $\log _{10}$ regressions between TPD and TW and $\mathrm{Ca}$ and $\mathrm{Cr}$ values Coastcross pastures.

\begin{tabular}{lcccccccccc}
\hline $\begin{array}{l}\text { Evaluation } \\
\text { date }\end{array}$ & $\beta_{0}$ & $\beta_{1}$ & Model & $\mathrm{r}^{2}$ & $\mathrm{P}_{\text {model }}$ & $\mathrm{Ca}$ & $\mathrm{SE}+\mathrm{Ca}$ & $\mathrm{Cr}$ & $\mathrm{SE}+\mathrm{Cr}$ & $\begin{array}{c}\text { Predicted } \\
\text { slope } \beta\end{array}$ \\
\hline 1 & 3,86 & $-2,05$ & $\mathrm{Y}=3,86-2,05 \mathrm{x}$ & 0,96 & 0,0192 & 0,87 & 0,35 & $-0,30$ & 0,26 & $-2,07$ \\
2 & 7,35 & $-2,92$ & $\mathrm{Y}=7,35-2,92 \mathrm{x}$ & 0,73 & 0,1472 & 1,93 & 0,701 & $-0,53$ & 0,13 & $-2,90$ \\
3 & 11,4 & $-3,83$ & $\mathrm{Y}=11,4-3,83 \mathrm{x}$ & 1,00 & 0,0262 & 2,11 & 1,286 & $-1,24$ & 1,19 & $-2,37$ \\
\hline
\end{tabular}

${ }^{*}$ Calculated according to Matthew et al. (1995), where slope $=-(\mathrm{Ca}+\mathrm{Cr}+3 / 2)$. Date $1=15 \mathrm{Dec} 1998$, Date $2=25$ Jan 1999 and Date $3=07$ Apr 1999. NS - Not significant

TABLE 14 - Distance between points with co-ordinates $x / y$ (in a log scale) and the $-3 / 2$ line, the sward leaf area index, at several sampling dates and their correlation coefficient and probability.

\begin{tabular}{lcccccc}
\hline & \multicolumn{2}{c}{ Evaluation 1 } & \multicolumn{2}{c}{ Evaluation 2 } & \multicolumn{2}{c}{ Evaluation 3 } \\
\hline $\begin{array}{l}\text { Sward } \\
\text { height cm }\end{array}$ & Distance & LAl & Distance & LAl & Distance & LAl \\
\hline 5 & 0,084 & 1,75 & 0,042 & 1,39 & 0,056 & 1,25 \\
10 & 0,126 & 2,43 & 0,194 & 2,16 & 0,236 & 2,24 \\
15 & 0,192 & 2,63 & 0,163 & 2,32 & 0,269 & 1,99 \\
20 & 0,190 & 2,55 & 0,302 & 3,16 & 0,380 & 2,81 \\
Correlation & 0,906 & 0,976 & 0,964 \\
Coeff. & 0,094 & 0,024 & 0,036 \\
Probability & &
\end{tabular}

Evaluation 1 = 15 Dec 1998, Evaluation 2 = 25 Jan 1999, Evaluation $3=07$ Apr 1999 .

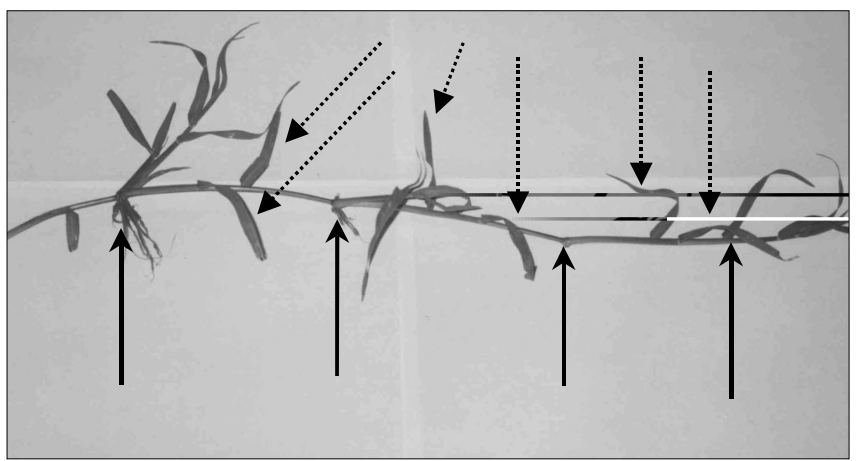

PLATE 1 - Cluster of new tillers being formed along a stolon at regular intervals of three phytomers; node with roots and daughter tiller (solid line) followed by two successive leaves (dotted lines).

The distance between the observed points and the $-3 / 2$ line and the actual sward LAI were correlated (TABLE 14). These coefficients were significant, indicating that the distance measured could, in fact, be used to predict LAI in Coastcross swards, a key sward structure variable, for a proper understanding of herbage accumulation processes in pastures (Lemaire \& Agnusdei, 1999). TW and TPD are sward variables that are easier to measure than LAl, justifying further studies in order to allow a better understanding of their relationship with sward LAI and intra-specific competition processes that could generate conditions for using them as predictors of LAI and herbage dry matter production. It is important to mention that the theory of Matthew et al. (1995) assumed all tillers in a population were of similar shape/ type with no variation in biomass per unit volume and a

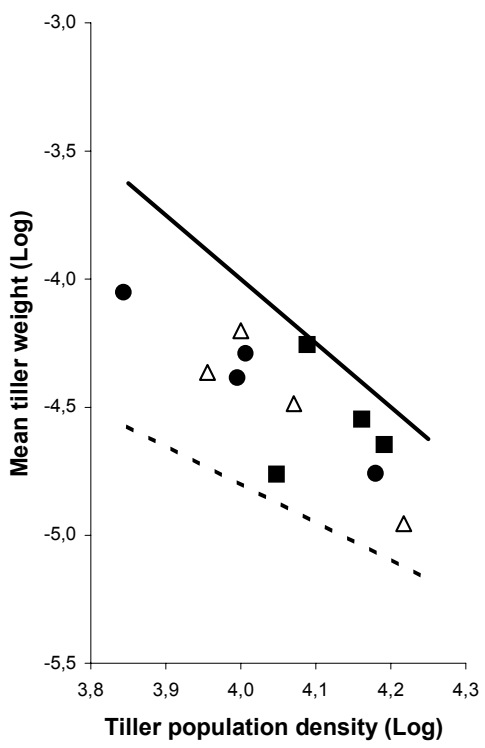

Figure 2 - Plot of log tiller weight and log tiller population density data in relation to $\left.-3 / 2(--)_{-}\right)$and $-5 / 2$ (-) selfthinning lines. • Evaluation $1(15 / 12 / 1998), \Delta$ Evaluation 2 (25/01/1999) and Evaluation 3 (07/04/1999).

new theory may be needed for mixed populations with different types/shapes of tillers mixed together with possible variations in tiller apparent density $\left(\mathrm{kg} \mathrm{DM} \mathrm{m}^{-3}\right)$.

\section{CONCLUSIONS}

The tiller size/density compensation mechanism originally described for temperate forage plants also operates in Coastcross pastures. As in temperate grasses, it follows a slope steeper than the theoretical proposition of $-3 / 2$.

$R$ values for Coastcross bermudagrass were lower (about 15) than for perennial ryegrass (about 50). A possible reason is that Cynodon tillers operate in groups (clusters) in order to ensure competitive ability and optimise LAl.

The SDC mechanism was dependent on time of the year with Coastcross pastures maintained at $5 \mathrm{~cm}$ sward height not being able to compensate for decreased tiller size by increasing tiller numbers during autumn.

The reproductive phase of growth interfered significantly with processes related to intra-specific competition and tiller population dynamics in Coastcross pastures. 


\section{ACKNOWLEDGMENTS}

To FAPESP (Fundação de Amparo à Pesquisa do Estado de São Paulo) for financial assistance and support, to the students of GEPF (Grupo de Estudos de Plantas Forrageiras) for their help and cooperation throughout the experimental period and to Dr. Cory Matthew, Massey University, New Zealand, for his valuable comments and suggestions during the execution of this experiment.

\section{REFERENCES}

BAHMANI, I.; THOM, E.R.; MATTHEW, C. Effects of nitrogen and irrigation on productivity of different ryegrass ecotypes when grazed by dairy cows. Proceedings of the New Zealand Grassland Association, v.59, p.117-123, 1998.

BINNIE, R.C.; CHESTNUTT, D.M.B. Effect of regrowth interval on productivity of swards defoliated by cutting and grazing. Grass and Forage Science, v.46, p.343-350, 1991.

BIRCHAM, J.S.; HODGSON, J. The influence of sward conditions on rates of herbage growth and senescence in mixed swards under continuous grazing management. Grass and Forage Science, v.38, p.323-331, 1983.

BRASIL. Ministério da Agricultura. Serviço Nacional de Pesquisa Agronômica. Comissão de Solos. Levantamento de reconhecimento dos solos do estado de São Paulo. Rio de Janeiro, 1960. 634p. (Boletim, 12).

CARNEVALLI, R.A.; Da SILVA, S.C. Avaliação de algumas características agronômicas e ecológicas de plantas da espécie Cynodon dactylon cv. Coastcross para fins de validação de técnicas para ensaios de pastejo com plantas forrageiras. Scientia Agricola, v.56, p.489-499, 1999.

COLVILL, K.E.; MARSHALL, C. Tiller dynamics and asimilate partitioning in Lolium perenne with particular reference to flowering. Annals of Applied Biology, v.104, p.543-557, 1984.

DAVIES, A. Structure of the grass swards. INTERNATIONAL MEETING ON ANIMAL PRODUCTION FROM TEMPERATE GRASSLAND, Dublin, 1977. Proceedings. Dublin, 1977. p.36-44.

DAVIES, A. The regrowth of grass swards. In: JONES, M.B.; LAZENBY, A. (Ed.) The grass crop. London: Chapman \& Hall, 1988. p.85-127.

ESCOLA SUPERIOR DE AGRICULTURA "LUIZ DE QUEIROZ" - ESALQ. Departamento de Ciências Exatas. http:// www.ciagri.usp.br/ endabreu/MEDIAS.TXT (20 set. 1999).

FAGUNDES, J.L. Efeito de intensidades de pastejo sobre o índice de área foliar, interceptação luminosa e acúmulo de forragem em pastagens de Cynodon spp. Piracicaba, 1999. 69p. Dissertação (Mestrado) - Escola Superior de Agricultura "Luiz de Queiroz", Universidade de São Paulo.

GRANT, S.A.; BARTHRAM, G.T.; TORVELL, L.; KING, J.; SMITH, H.K. Sward management lamina turnover and tiller population density in continuously stocked Lolium perenne - dominated swards. Grass and Forage Science, v.38, p.333-344, 1983.

HERNÁNDEZ GARAY, A.; MATTHEW, C.; HODGSON, J. Tiller size-density compensation in ryegrass miniature swards subject to differing defoliation heights and a proposed productivity index. Grass and Forage Science, v.54, p.347356, 1999.

HODGSON, J. Grazing management: science into practice. Essex: Longman Scientific \& Technical, 1990. 203p.

KAYS, S.; HARPER, J.L. The regulation of plant and tiller density in a grass sward. Journal of Ecology, v.62, p.97-105, 1974.
KORTE, C.J. Tillering in "Grasslands Nui" perennial ryegrass swards: 2. Seasonal pattern of tillering and age of flowering tillers with two mowng frequencies. New Zeland Journal of Agricutural Research, v.29, p.629-638, 1986.

LAMBERT, M.G.; CLARK, D.A.; GRANT, D.A.; COSTALL, D.A.; GRAY, Y.S. Influence of fertiliser and grazing management on North Island moist hill country 4. Pastures species abundance. New Zealand Journal of Agricultural Research, v.29, p.23-31, 1986.

LANGER, R.H.M. Tillering. In: LANGER, R.H.M. (Ed.) How grasses grow. London: Edward Arnold, 1979. cap. 5p.19-25.

LEMAIRE, G.; AGNUSDEI, M. Leaf tissue turn-over and efficiency of herbage utilisation. In: SIMPÓSIO INTERNACIONAL GRASSLAND ECOPHYSIOLOGY AND GRAZING ECOLOGY, 1., Curitiba, 1999. Anais. Curitiba: UFPR, 1999. p.165-183.

LONSDALE, W.M.; WATKINSON, A.R. Light and self-thinning. New Phytologist, v.90, p.431-445, 1982.

MATTHEW, C. A study of seasonal root and tiller dynamics is swards of perennial ryegrass (Lolium perenne L.) Palmerston North, 1992. 110p. Thesis (Ph.D.) - Massey University.

MATTHEW, C.; LEMAIRE, G.; SACKVILLE HAMILTON, N.R.; HERNÁNDEZ GARRAY, A. A modified self-thinning equation do describe size / density relationships for defoliated swards. Annals of Botany, v.76, p.579-587, 1995.

MATTHEW, C.; ASSUERO, S.G.; BLACK, C.K.; SACKVILLE HAMILTON, N.R. Tiller dynamics of grazed swards. In: SIMPÓSIO INTERNACIONAL GRASSLAND ECOPHYSIOLOGY AND GRAZING ECOLOGY, 1., Curitiba, 1999. Anais. Curitiba: UFPR, 1999. p.109-133.

McMAHON, C. Size and shape in biology. Science, v.179, p.1201-1204, 1973.

McMAHON, C.; KRONAUER, R.E. Tree structures: deducing the principle of mechanical design. Journal of Theoretical Biology, v.59, p.443-466, 1976.

MITCHELL, K.J.; GLENDAY, A.C. The tiller population of pastures. New Zealand Journal of Agricultural Research, v.1, p.305-318, 1958.

NELSON, C.J.; ZARROUGH, K.M. Tiller density and tiller weight as yield determinants of vegetative swards. Plant Physiology and Herbage Production, n.13, p.25-29, 1981. (Occasional Symposium).

NIKLAS, K.J. Plant allometry: the scaling process. Chicago: University of Chicago Press, 1994. 395p.

OMETTO, J.C. Registros e estimativas dos parâmetros meteorológicos da região de Piracicaba, SP. Piracicaba: FEALQ, 1989. 76p.

SACKVILLE HAMILTON, N.R.; MATTHEW, C.; LEMAIRE, G. In defence of the $-3 / 2$ boundary rule: a re-evaluation of selfthinning concepts and status. Annals of Botany, v.76, p.569577, 1995.

SAS INSTITUTE. SAS user's guide: release 6.03. Cary: Statistical Analysis System Institute, 1988. 1028p.

THOM, E.R.; BRYANT, A.M. Effects of grazing management on grass tiller density characteristics of a ryegrass-white clover dairy pasture. In: INTERNATIONAL GRASSLAND CONGRESS, 17., Palmerston North, 1993. Proceedings. Palmerston North: Keeling and Mundy, 1993. p.877-899.

VOLENEC, J.J.; NELSON, C.J. Responses of tall fescue leaf meristems to $\mathrm{N}$ fertilization and harvest frequency. Crop Science, v.23, p.720-724, 1983.

WELLER, D.E. Self-thinning exponent correlated with allometric measures of plant geometry. Ecology, v.68, p.813-821, 1987.

WELLER, D.E. The interspecific size-density relationship among crowded plant stands and its implication for the $-3 / 2$ power rule of self-thinning. American Naturalist, v.133, p.20-41, 1989. 
WELLER, D.E. Will the real self-thinning rule please stand up? A reply to Osawa and Sugita. Ecology, v.71, p.1204-1207, 1990.

WELLER, D.E. The self-thinning rule - dead or unsupported? A reply to Lonsdale. Ecology, v.72, p.747-750, 1991.

WESTOBY, M. The self-thinning rule. Advances in Ecological Research, v.14, p.41-76, 1984.

WHITE, J. Demographic factors in population of plants. In: SOLBRIG, O.T. (Ed.) Demography and evolution in plant population. Berkeley: University of California Press, 1980. p.21-48.

WHITE, J. The allometric interpretation of the self-thinning rule. Journal of Theoretical Biology, v.89, p.475-500, 1981.

WHITE, J. The thinning rule and its application to mixtures of plant populations. In: WHITE, J. (Ed.) Studies on plant demography. London: Academic Press, 1985. p.291-309.

WHITE, J.; HARPER, J.L. Correlated changes in plant size and number in plant populations. Journal of Ecology, v.58, p.467485, 1970.
YANG, J.Z.; MATTHEW, C.; ROWLAND, R.E. Tiller axis observations for perennial ryegrass (Lolium perenne L.) and tall fescue (Festuca arundinaceae Schreb.): number of active phytomers, probability of tiller appearance and number of roots per phytomer for three cutting heights. New Zealand Journal of Agricultural Research, v.41, p.11-19, 1998.

YODA, K.; KIRA, T.; OGAWA, H.; HOZUMI, K. Intraspecific competition among higher plants. XI Self-thinning in overcrowded pure stands under cultivated and natural conditions. Journal of Institute of Polytechnics, v.14, p.107129, 1963. (Osaka City University. Series D).

ZEIDE, B. Tolerance and self-tolerance of trees. Forest Ecology and Management, v.13, p.149-166, 1985.

ZEIDE, B. Analysis of the $3 / 2$ power law of self-thinning. Forest Science, v.33, p.517-523, 1987.

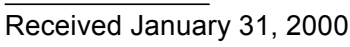

